\title{
Использование Sn в качестве катализатора роста бездислокационных наноструктур SiSn
}

\author{
В.А. Тимофеев ${ }^{1)}$, В.И. Машанов ${ }^{1)}$, А.И. Никифоров ${ }^{1,2)}$, Т.А. Гаврилова ${ }^{1)}$, Д.В. Гуляев ${ }^{1)}$, И.А. \\ Четырин $^{3)}$, С.А. Тийс ${ }^{1)}$, А.К. Гутаковский ${ }^{1)}$ \\ ${ }^{1}$ Институт физики полупроводников илени А.В. Ржанова СО РАН, \\ Новосибирск, 630090, пр. Ак. Лаврентьева, 13 \\ ${ }^{2}$ Томский государственный университет, Томск, 634050, пр. Ленина 36 \\ ${ }^{3}$ Институт катализа имени Г.К. Борескова СО РАН, Новосибирск, 630090, пр. Ак. Лаврентьева 5 \\ тел:+7 (383) 330-7934, эл.nочта: Vyacheslav.t@isp.nsc.ru
}

DOI 10.34077/RCSP2019-116

Интерес к классу материалов Si-Ge-Sn значительно возрос в последние годы в связи с возможностью реализации прямозонного материала и монолитной интеграции электронных и фотонных устройств на едином кремниевом кристалле $[1,2]$. Большинство исследований направлены на создание структур на основе GeSn и GeSiSn. Тем не менее, SiSn также является важным материалом для кремниевой фотоники.

Наши исследования были посвящены изучению влияния Sn на образование твердого раствора $\mathrm{SiSn}$ на подложке $\mathrm{Si}(100)$ методом молекулярно-лучевой эпитаксии. Вначале на поверхности $\mathrm{Si}$ формировалась пленка $\mathrm{Sn}$ различной толщины, а затем отжигалась для создания массива островков $\mathrm{Sn}$, которые использовались в качестве катализаторов роста островков $\mathrm{SiSn}$ с кремниевыми пьедесталами. Основным методом контроля морфологии и структуры поверхности была дифракция

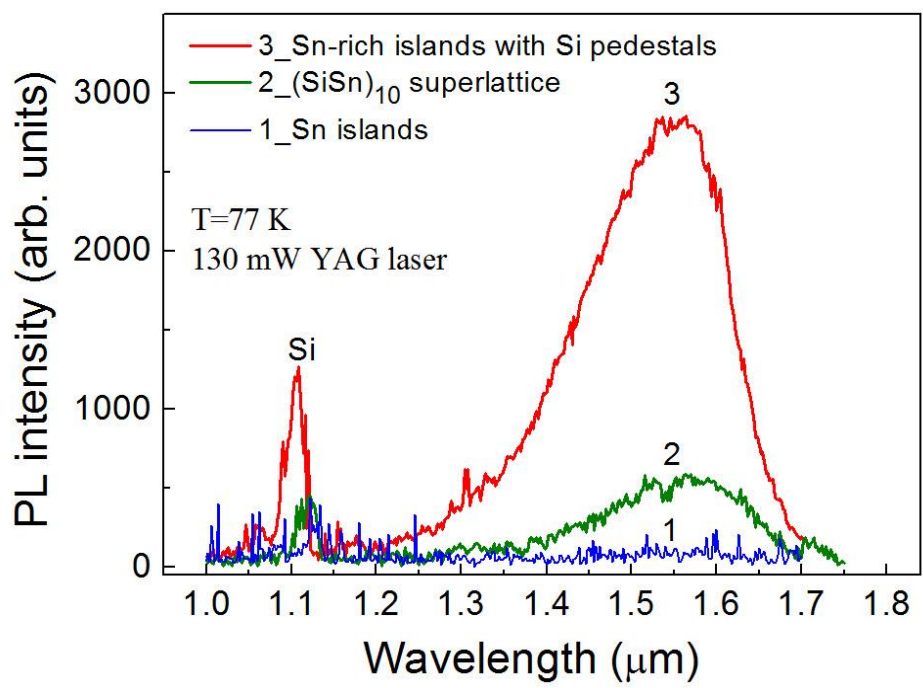

Рисунок. Спектры фотолюминесценции от образца, содержащего островки Sn (1), от образца, включающего сверхрешетку (2) с гетеропереходом $\mathrm{Si} / \mathrm{Si}_{0.75} \mathrm{Sn}_{0.25}$, и от образца с островками $\mathrm{SiSn}(3)$.

быстрых электронов. Морфологию пленки, включая островки $\mathrm{Sn}$ и островки $\mathrm{SiSn}$ с пьедесталами, анализировали с помощью сканирующей электронной микроскопии (СЭМ) и сканирующей туннельной микроскопии. Элементный состав исследовали методами энергодисперсионной рентгеновской спектроскопии, встроенной в систему СЭМ, и рентгеновской фотоэлектронной спектроскопии (РФС). Оптические свойства образцов изучали методом спектроскопии фотолюминесценции (ФЛ).

Массив островков SiSn с кремниевым пьедесталом на подложке $\operatorname{Si}(100)$ получен методом молекулярно-лучевой эпитаксии по механизму пар-жидкость-кристалл (ПЖК) [3]. Образование твердого раствора SiSn в островках было подтверждено методами энергодисперсионной рентгеновской спектроскопии и РФС. Уникальность этих структур заключается в отсутствии каких-либо дислокаций и дефектов. Кроме того, они продемонстрировали интенсивную фотолюминесценцию в ближней инфракрасной (ИК) области 1,3-1,7 мкм (рисунок). Эти структуры показывают фотолюминесценцию, которая больше, чем сигнал фотолюминесценции от многослойных периодических структур (кривая 2 на рисунке), включая псевдоморфные слои SiSn и полученные нами ранее.

\section{Лumepamypa}

[1] T. R. Harris et al. // J. Appl. Phys. 2016. V.120, P.085706.

[2] S. Assali et al. // Nano Letters. 2017. V. 17, P.1538.

[3] Е.И. Гиваргизов. Рост нитевидных и пластинчатых кристаллов из пара // М.: Наука. 1977. С. 303. 